\title{
Psychologism and the Self
}

\section{Vincente Sanfelix Vidarte}

\section{(2) OpenEdition}

\section{Journals}

Electronic version

URL: http://journals.openedition.org/ejpap/1001

DOI: 10.4000/ejpap.1001

ISSN: 2036-4091

\section{Publisher}

Associazione Pragma

Electronic reference

Vincente Sanfelix Vidarte, «Psychologism and the Self », European Journal of Pragmatism and American Philosophy [Online], IX-1 | 2017, Online since 22 July 2017, connection on 11 June 2020. URL : http:// journals.openedition.org/ejpap/1001 ; DOI : https://doi.org/10.4000/ejpap.1001

This text was automatically generated on 11 June 2020.

\section{(c) (i) $\odot$

Author retains copyright and grants the European Journal of Pragmatism and American Philosophy right of first publication with the work simultaneously licensed under a Creative Commons AttributionNonCommercial-NoDerivatives 4.0 International License. 


\title{
Psychologism and the Self
}

\author{
Vincente Sanfelix Vidarte
}

\section{AUTHOR'S NOTE}

This article forms part of research project FFI2016-76856-R, financed by the Spanish Government's Ministry of Economy and Competitiveness.

\section{Wittgenstein, the Reader of James}

1 William James is one of the authors most cited and referred to in the writings that Wittgenstein left at his death, ${ }^{1}$ despite which it is only recently that scholars of the Austrian philosopher have devoted themselves to the analysis of the relation of their respective thoughts. Russell B. Goodman, one of the pioneers in this task, describes the stage of Wittgensteinian hermeneutics prior to his own work:

Some of the best commentators on the Investigations [...] ignore Wittgenstein's references to James entirely. Others who notice James' influence [...] see Wittgenstein not as having learned from James, but as predominantly critical of him. (Goodman 2002: 62)

Well, it can now be said that this interpretation of Wittgenstein's attitude to James as "merely critical and negative" is no longer tenable. It is evident that Wittgenstein did not only disagree with the American thinker but also accepted many of his points of view. And not only those expressed in The Varieties of Religious Experience, one of James's books of which Wittgenstein always spoke enthusiastically, ${ }^{3}$ but also in The Principles of Psychology, the book that at one time he thought of using as a "target" for his criticisms in his classes. ${ }^{4}$

3 Moreover, although it is very plausible to think that some of the most profound assumptions of the philosophical tradition when it discusses the nature of the mental such as the possibility of the existence of a private language - which Wittgenstein destroys were considered by him as implied by the introspective method that James 
recommended and practised in his Principles, ${ }^{5}$ it is no less true that other criticisms that Wittgenstein directs at the American thinker seem to be off the mark or to be simply unfair.

4 Let's take two examples that will concern us especially: Wittgenstein's criticism of the supposed scientific status of James's psychology, and his criticism of the conception of the self that the author of The Principles assumes.

In Manuscript 165 of the Nachlass Wittgenstein wrote:

How necessary is the work of philosophy is shown by James's Psychology. Psychology, he says, is a science. But he discusses almost no scientific questions. His movements are merely attempts to free himself from the cobwebs of metaphysics in which he is caught. He cannot yet walk, or fly at all, he only wriggles: not that that is not interesting. Only it is not a scientific activity. (Wittgenstein 2000: MS 165: 150-1)

Wittgenstein is quite right, as even James would willingly have conceded. At least if we take account of the confession that he makes to Holt, the publisher of his Principles, to whom he describes his work in the following terms:

a loathsome, distended, tumefied, bloated, dropsical mass, testifying to nothing but two facts: 1st, that there is no such thing as a science of psychology, and 2nd, that W. J. is an incapable. (James 1926: 393-4)

and in the epilogue of his abbreviated version of the Principles he adds:

This is no science, it is only the hope of a science. The matter of a science is with us [...] at present psychology is in the condition of physics before Galileo and the laws of motion, of chemistry before Lavoisier and the notion that mass is preserved in all reactions. The Galileo and the Lavoisier of psychology will be famous men indeed when they come, as come they some day surely will, or past successes are no index to the future. (James 1892b: 468)

However, may not these words of James's be at the origin of Wittgenstein's reflection that practically concludes the fragment of philosophy of psychology published as the second part of his Investigations? Remember:

The confusion and barrenness of psychology is not to be explained by its being a "young science"; its state is not comparable with that of physics, for instance, in its beginnings. (Rather, with that of certain branches of mathematics. Set theory.) For in psychology, there are experimental methods and conceptual confusion. (As in the other case, conceptual confusion and methods of proof.) The existence of the experimental method makes us think that we have the means of getting rid of the problems which trouble us; but problem and method pass one another by. (Wittgenstein 2009: II, XIV, 371)

It does not seem to be a far-fetched hypothesis. And what seems to follow from it is that both James and Wittgenstein might agree in pointing to the limitations of psychology as science, but whereas, according to Wittgenstein, James would conceive those limitations as being merely empirical, he himself would understand them as being basically conceptual. Now, would this interpretation be fair to James? I suspect not.

At the very beginning of Chapter VI of his Principles, we read:

The reader who found himself swamped with too much metaphysics in the last chapter will have a still worse time of it in this one, which is exclusively metaphysical. Metaphysics means nothing but an unusually obstinate effort to think clearly. The fundamental conceptions of psychology are practically very clear to us, but theoretically they are very confused, and one easily makes the obscurest assumptions in this science without realizing, until challenged, what internal difficulties they involve. When these assumptions have once established themselves 
(as they have a way of doing in our very descriptions of the phenomenal facts) it is almost impossible to get rid of them afterwards or to make anyone see that they are not essential features of the subject. The only way to prevent this disaster is to scrutinize them beforehand and make them give an articulate account of themselves before letting them pass. (James 1983: 148) ${ }^{6}$

11 If I refer to this text of James's it is not with a view to specifying how he understood the relations between psychology and philosophy (a matter to which we shall return later), ${ }^{7}$ but to show that any mere accusation of his having ignored the conceptual problems that the former entails - and that the latter seeks to clarify - is simply wide of the mark. James would be completely in agreement with Wittgenstein that "in psychology, there are experimental methods and conceptual confusion" (original emphasis); what is more, like Wittgenstein he would consider that the main source of this conceptual confusion must be attributed to the structure of our language, ${ }^{8}$ and that it is not dissolved by the mere application of experimental methods. And he would also agree that his Principles are not basically the result of application of the experimental method - we have already drawn attention to the preponderance in him of introspective observation and the comparative method - and that they contain a good deal of "metaphysics."

Let's look briefly at the other example that we promised to consider. In §143 of the first part of the Philosophical Investigations we read:

Here we have a case of introspection, not unlike that which gave William James the idea that the "self" consisted mainly of "peculiar motions in the head and between the head and throat." And James's introspection showed, not the meaning of the word "self" (so far as it means something like "person," "human being," "he himself," "I myself"), or any analysis of such a being, but the state of a philosopher's attention when he says the word "self" to himself and tries to analyse its meaning. (And much could be learned from this.) (Wittgenstein 2009: § 143)

13 The passage to which Wittgenstein refers appears in Chapter X of The Principles, and what it says is this:

In a sense, then, it may be truly said that, in one person at least, the "Self of selves," when carefully examined, is found to consist mainly of the collection of these peculiar motions in the head or between the head and throat. (James 1983: 288; original emphasis)

14 In this passage, is James trying to use introspection to analyse the meaning of the word "self"? Might this be his objective in this chapter of his book? Without needing to apply any interpretative charity, the answer to both questions is clearly in the negative.

In the passage to which Wittgenstein refers, situated in the context of his discussion of "The Spiritual Self" (one of the three constituents of "The Empirical Self of Me," the other two being "The Material Self" and "The Social Self"), ${ }^{10}$ what James wants is to point out that the "feeling" that corresponds to our spiritual activity really corresponds to bodily activities that are generally unnoticed, as the continuation of the passage makes quite clear:

I do not for a moment say that this is all it consists of, for I fully realize how desperately hard is introspection in this field. But I feel quite sure that these cephalic motions are the portions of my innermost activity of which I am most distinctly aware. If the dim portions which I cannot yet define should prove to be like unto these distinct portions in me, and I like other men, it would follow that our entire feeling of spiritual activity, or what commonly passes by that name, is really a feeling of bodily activities whose exact nature is by most men overlooked. (original emphasis) 
And with regard to the long and complex chapter - the second longest in the book ${ }^{11}$ - in which this passage appears, its very title, "The consciousness of Self," shows that James's interest is not in the meaning of the word "Self" but in what it is and the awareness of it that we may have.

In other words, Wittgenstein seems to be attributing to James the aims of his own grammatical investigation and going on to point out James's mistakes - but James did not have those aims, for the simple reason that he did not conceive his investigation as grammatical.

18 The conclusion to which I wish to come with the mere analysis of these two examples is that the relation between James's and Wittgenstein's points of view is extremely complex; and that, of course, justice is not done to it if all that is said is that the latter is a critic of the former. The philosophy of the late Wittgenstein may certainly represent a criticism of some of the central assumptions of James's psychology, but it is no less true that Wittgenstein sometimes agrees with James - even when he seems to criticise him - and sometimes the Austrian uses the American thinker for purposes that were quite foreign to him.

19 In any case, Wittgensteinian hermeneutics has changed and there are many scholars who no longer consider that the relation between these two thinkers is merely critical and negative; ${ }^{12}$ yet it is equally true that the comparison of their respective philosophies of psychology - as opposed to their positions in philosophy of religion has been confined to the so-called second Wittgenstein. However, we believe that extending the comparison to the first Wittgenstein may prove enlightening, and it is to this task that we are going to devote ourselves in the remaining pages, concentrating our interest on two questions that are undoubtedly central in the thinking of both men: psychologism and the understanding of the self.

\section{Theory of Knowledge and Philosophy of Psychology}

20 As I have just noted, there is no lack of reasons for confining the comparison of their respective philosophies to the second Wittgenstein. James is referred to in the Nachlass for the first time in a manuscript of 1932, and for the last time in one of 1950-51. If the comparison of their respective philosophies of religion is extended to the first Wittgenstein it is because it is documentarily justified, for, in a letter of 22 June 1912 addressed to Russell, Wittgenstein informs him that he is reading The Varieties of Religious Experience, a book that is doing him "a lot of good."13

21 Now, in the same letter Wittgenstein informs Russell of the discussion that he had had "with Myers about the relations between Logic and Psychology." ${ }^{14}$ So from this letter we can be sure of two things: 1) that by 1912 Wittgenstein was interested in James, and 2) that he was concerned about the relation between logic and psychology. If this is so, however, is it implausible to think that he then read, however fragmentarily, the Principles or the Briefer Course (remembering that the epilogue of this latter book is precisely about the relation between philosophy and psychology)?

22 As I understand it, this hypothesis gains plausibility if we take another factor into account: the relation that his mentor in Cambridge at that time, i.e. Bertrand Russell, had with pragmatism in general and with James in particular. 

the young Wittgenstein moves, I think that light is cast on his early consideration of 
the equivalence of the theory of knowledge and the philosophy of psychology which clarifies it to a great extent.

In fact, for both James and Russell there was a close relation between the theory of knowledge and psychology. Thus, the American psychologist writes: "In German philosophy since Kant the word Erkenntnisstheorie, criticism of the faculty of knowledge, plays a great part. Now the psychologist necessarily becomes such an Erkenntnisstheoretiker" (James 1983: 184). And Russell, in turn, writes in his Theory of Knowledge that "much of epistemology is included in psychology" and that, however, as soon as the theory of judgment is reached, "a difficult and interesting problem of pure logic arises, namely the problem of enlarging the inventor of logical forms so as to include forms appropriate to the facts of epistemology," so concluding "that it is impossible to assign to the theory of knowledge a province distinct from that of logic and psychology." ${ }^{21}$

31 So, for a reader familiar with the thought of James and Russell, it should not be in the least surprising that Wittgenstein considers epistemology and philosophy of psychology to be equivalent. Yet, if we reflect a little, we will soon come to the conclusion that with this consideration of equivalence Wittgenstein is moving away critically from Russell and perhaps even more from James.

\section{The Psychologism Dispute: Philosophy and Psychology}

32 In fact, whereas James simply seems - later we shall see the reason for this cautious formula - to identify the figures of the psychologist and the theorist of knowledge, Russell appears to conceive of the theorist of knowledge as a hybrid being: half psychologist, half logician. And Wittgenstein? Wittgenstein identifies the theory of knowledge, strictly, with the philosophy - which in turn, remember, he has said consists simply of logic and metaphysics - of psychology. That is to say that for him the theory of knowledge was either logic or metaphysics of psychology, but not psychology!

Logic or metaphysics? If we put the architectural passage from the "Notes on Logic" that we cited earlier in relation to the passage from Russell's Theory of Knowledge that we have just evoked, the dilemma seems to declare itself in favour of the former. We must remember that Wittgenstein characterised philosophy as "the doctrine of the logical form of scientific propositions," whereas Russell, in turn, characterised as an "interesting problem of pure logic [...] the problem of enlarging the inventor of logical forms so as to include forms appropriate to the facts of epistemology." If we consider them together, the most likely interpretation, as I understand it, of what Wittgenstein means when he identifies the theory of knowledge with the philosophy of psychology is that the former is a part of logic: the application of logic to psychological propositions.

We see, therefore, that James, Russell and Wittgenstein represent three different, but continuous, conceptions of the theory of knowledge. James seems - we repeat: seems to identify the theory of knowledge with psychology, as Quine (1969) was to do over half a century later in launching his proposal of the naturalisation of epistemology. Russell considers the theory of knowledge as a hybrid discipline between psychology and logic. Finally, Wittgenstein appears to understand the theory of knowledge as a 
chapter of logic: the logic that deals with establishing the logical form of psychological propositions. As a result of which, as we can now understand, he is able to define it as the philosophy of psychology while maintaining that philosophy consists only of metaphysics and logic.

And we can understand, too, that condensed in that identification that Wittgenstein makes there is a criticism of the positions both of Russell and of James and, in general, of all those who in one way or another, to a greater or lesser extent, have conceded that philosophical problems - for example, epistemological problems - come within the competence of psychology. And thus, in Tractatus 4.1121, he glosses his early identification of the theory of knowledge with the philosophy of psychology in this way:

Psychology is no more closely related to philosophy than any other natural science. Theory of knowledge is the philosophy of psychology. Does not my study of signlanguage correspond to the study of thought-processes, which philosophers used to consider so essential to the philosophy of logic? Only in most cases they got entangled in unessential psychological investigations, and with my method too there is an analogous risk. (Wittgenstein 2001: 4.1121)

This is how Wittgenstein intervened in the discussion that had arisen at the end of the nineteenth century and beginning of the twentieth about the respective competences of philosophy and psychology: the "psychologism dispute" (Psychologismus-Streit); and he did so from an even more radical anti-psychologist position than that of Russell himself, defending that "Psychology is no more closely related to philosophy than any other natural science" and that "the study of thought-processes, which philosophers used to consider so essential," in most cases proved to be simply "unessential psychological investigations" (Wittgenstein 2011: 4.1121).

If we were to seek an absolutely antithetical position to Wittgenstein's, perhaps we might find it in Brentano's book Psychology from an Empirical Standpoint, in the first chapter of which - "The Concept and Purpose of Psychology" - the Austro-German thinker conceives of psychology, which he describes as "the science of the future" (Brentano 1995: 19), as the basis of logic, aesthetics, ethics and even of politics; ${ }^{22}$ for which reason it is called upon to play a decisive part in the progress of humanity, even providing us with the means to neutralise cultural decadence. ${ }^{23}$

However, although James knew Brentano's work, to anyone who has the slightest familiarity with his writings about Psychology it is evident that he did not share the latter's psychologistic enthusiasm. Yet did he not identify the figure of the psychologist with that of the epistemologist? Did that not imply a proposal of naturalisation of epistemology and a form of psychologism?

In my view, the answer to these questions must be no, ${ }^{24}$ and that is why I used a prudent expression earlier when I outlined James's position in contrast with those of Russell and Wittgenstein. To see this we must return to the subject that we left pending in the first section of this paper, about how James conceives of the relation between Philosophy and Psychology.

In his 1892 essay "A plea for Psychology as a 'natural science'," James asks: "What is a natural science, to begin with?" And he replies:

It is a mere fragment of truth broken out from the whole mass of it for the sake of practical effectiveness exclusively. Divide et impera. Every special science, in order to get at its own particulars at all, must make a number of convenient assumptions and decline to be responsible for questions which the human mind will continue to 
ask about them [...] Between the things thus assumed, now, the various sciences find definite "laws" of sequence; and so are enabled to furnish general Philosophy with materials properly shaped and simplified for her ulterior tasks. (James 1920: 317-8)

This excellent essay in a way condenses the understanding that James has of the relation that exists between philosophy and science, and therefore between philosophy and psychology. All science presupposes a double limitation. For a start, that of its object of study, for any science begins by defining the boundaries, within the whole of reality, of an area of phenomena whose laws are those that it proposes to investigate. And then, that of its basic assumptions, the problematisation of which it renounces, at least in so far as their practical efficacy - which James evaluates especially in terms of their predictive ability ${ }^{25}$ is maintained.

Now, even if science were to formulate some definitive principles to enable it to comply perfectly with its practical objectives and adjust itself totally to our experience of the world, something that is unthinkable for James in view of his dynamic understanding of experience ${ }^{26}$ the human mind would still continue wondering about these questions that science renounces posing, and aspiring to a general, and not just fragmentary, view of reality.

Well, it is from this twofold aspiration that philosophy originates:

Metaphysics means only an unusually obstinate attempt to think clearly and consistently. The special sciences all deal with data that are full of obscurity and contradiction; but from the point of view of their limited purposes these defects may be overlooked. Hence the disparaging use of the name metaphysics which is so common. To a man with a limited purpose any discussion that is over-subtle for that purpose is branded as "metaphysical" [...]. But it is obvious that problems irrelevant from one standpoint may be essential from another. And as soon as one's purpose is the attainment of the maximum of possible insight into the world as a whole, the metaphysical puzzles become the most urgent ones of all. (James 1892b: 461-2)

43 We understand now how far James is from any simplistically positivist understanding of the relation between science and philosophy, or of any radical proposal of naturalisation of it. The development of science can never do away with philosophy, nor can philosophy ever be reduced to a science.

But if James is not a reductive naturalist in metaphilosophical questions, then he can also not be a supporter of psychologism, because, after all, psychologism is simply one of the forms of this kind of reductionist naturalism. Precisely if psychology wishes to aspire to become a natural science, it will have to share the limitations of the other sciences with them, supplying materials to philosophy instead of supplanting them.

We now consider fully justified the caution that we showed earlier when we compared James's position with those of Russell and Wittgenstein concerning the relation between psychology and epistemology. Resistant as he is to psychologism, James would not subscribe to Quine's proposal of reduction of the theory of knowledge to psychology. In fact, the passage that we cited earlier in which he seems to identify the psychologist with the epistemologist continues thus:

Now the psychologist necessarily becomes such an Erkenntnisstheoretiker. But the knowledge he theorizes about is not the bare function of knowledge which Kant criticises - he does not inquire into the possibility of knowledge überhaupt. He assumes it to be possible. (James 1983: 184) 
And in case it is not clear, in the following chapter, in which he deals with "The Relations of Minds to Other Things," he adds:

Now the relation of knowing is the most mysterious thing in the world. If we ask how one thing can know another we are led into the heart of Erkenntnisstheorie and metaphysics. The psychologist, for his part, does not consider the matter so curiously as this. (James 1983: 212)

If, owing to their intentional character, mental states have a cognitive dimension, the psychologist might well be considered the natural scientist Erkenntnisstheoretiker par excellence. Taking for granted the cognitive validity of our mental states, he can ask himself particular questions such as, to take a classic example, how it is possible that we perceive the size of an object as constant despite the fact that it produces an ever smaller retinal image as it moves away from us. But what the psychologist, qua psychologist, cannot and must not do - if he wishes to remain within the bounds of natural science - is to ask himself about "the possibility of knowledge überhaupt," i.e. in general. This problem, the problem of whether one can know something in absolute terms, is the central problem of epistemology or theory of knowledge, and as such it is a strictly metaphysical problem. ${ }^{27}$

\section{The Psychologism Dispute: Psychology and Logic}

Thus we might well say that James's metaphilosophical position is as anti-psychologist as that of the early Wittgenstein, except one would have to add that they are different anti-psychologisms because, as we have seen, the young Wittgenstein considers that the theory of knowledge is nothing but logic, and James considers that the theory of knowledge is metaphysics. ${ }^{28}$

It is not really difficult to form an idea of what James might have thought of the first Wittgenstein's position if he had known it. Probably something very similar to what he thought about Russell's manner of dealing with the - epistemologically central problem of truth, that it is a kind of innocuous "logical abstractionism." 29

Finding the logical form of psychological propositions - the task to which the young Wittgenstein seems to reduce the theory of knowledge - is still a form of "logical abstractionism"; and although, as we shall see later, that logical task that Wittgenstein sets himself is not as innocuous as it might seem, the truth is that at this point it is James who appears to be in the right. Logical abstractionism cannot give an account of the central problems of the theory of knowledge.

51 And the fact is that, even if we bring to light the real logical form of psychological propositions or any other propositions, scientific or ordinary, and even if we manage to design a logical notation that avoids any confusion in this regard, there will always be irreducibly metaphysical problems such as how it is possible that language describes reality, or the very problem of the truth of our descriptions of it. Problems that Wittgenstein himself could not avoid facing in the Tractatus, which may perhaps explain his warning, given, as we have seen, in the very paragraph in which he equated the theory of knowledge with the philosophy of psychology, of the danger that his own method might end up "entangled in unessential psychological investigations."

52 Concerning the strategy that the young Wittgenstein followed to try to avoid this danger, here we will only say two things. First: that it has an unquestionably Kantian 
aroma, in making the relation of thought and language with the world correspond to a subject that is not empirical but transcendental. Second: that at some points, such as his understanding of truth, his theses are not as compatible with James's points of view as they might seem to be at first sight..$^{30}$

In any case, the psychologism dispute does not have only the metaphilosophical dimension, concerning the relation between epistemology and psychology, that we have just considered. It also has another dimension that affects the philosophy of logic more specifically. In this regard, psychologism can be understood as a concretion of the empiricist conceptions that seek to make logic depend on a contingent order: of the world, of our experience of it or of our particular mental structure. Can it be said that in this restricted sense James is a psychologist? ${ }^{31}$ Would his position at this point diverge from Wittgenstein's?

The answers to these questions are not easy. In the last chapter of his Principles James deals with the question of "Necessary Truths and the Effects of Experience." At the beginning of the chapter he also distinguishes between necessary propositions - such as "the opposite sides of a parallelogram are equal" - and contingent propositions such as "tomorrow will be rainy." Concerning the latter he tells us that they are something that "is universally admitted to be due to 'experience"'; with regard to necessary propositions he says that they are "ascribed to the 'organic structure' of the mind," and adds:

[t]his structure is in turn supposed by the so-called apriorists to be of transcendental origin, or at any rate not to be explicable by experience; whilst by evolutionary empiricists it is supposed to be also due to "experience," only not to the experience of the individual, but to that of his ancestors as far back as one may please to go. (James 1983: 1215)

Which of these two options is the one James chooses? He himself replies: "On the whole, then, the account which the apriorists give of the facts is that which I defend; although I should contend [...] for a naturalistic view of their cause" (original emphasis). That is to say that James opposes any empiricist explanation of logical and mathematical truth. The necessary truths of which these disciplines are made up do not have their origin in experience, whether it is that of the individual or of the species.

Since Wittgenstein, in the Tractatus, explicitly defends the transcendental character of logic - "Logic is transcendental," we read in proposition 6.13 - it seems that we should situate the Austrian philosopher in the same ranks of the "apriorists" in which James includes himself, and both, in turn, on the side of the anti-psychologism; if we understand, as we have said, that psychologism is akin to the empiricist philosophies of logic.

However, this conclusion is not as evident as it appears at first, or at least it requires more than one qualification. For although it is quite clear that they both reject the empiricist explanations of necessity of logic and mathematics, it is no less clear that they seem to do so from different perspectives. As we have just seen, Wittgenstein assumes a philosophy of logic of a transcendental kind, whereas James opts for a markedly naturalist position. It seems, therefore, that here there is something similar to what we saw earlier with regard to the metaphilosophical dimension of psychologism, when their common opposition to the reduction of the theory of knowledge to psychology did not prevent the existence of profound differences in their 
respective understandings of epistemology. Except that now the comparison between James's and Wittgenstein's philosophies of logic is even more complex.

Indeed, for the young Wittgenstein logic is transcendental because of its function, since in his opinion respect for its rules is the sine qua non of the intelligibility of any description that we may give of reality. Hence, in the same proposition of the Tractatus in which he says that logic is transcendental (6.13), he notes that it "is not a body of doctrine, but a mirror-image of the world." Thus the first Wittgenstein's philosophy of logic is functionally transcendental.

On the other hand, the transcendentalism that James opposes is a genetic transcendentalism. It is the position that in philosophy of logic attributes a transcendent origin to our a priori mathematical logic. In his essay on "Humanism and Truth" to which we referred earlier he writes:

"God geometrizes," it used to be said; and it was believed that Euclid's elements literally reproduced his geometrizing. There is an eternal and unchangeable "reason"; and its voice was supposed to reverberate in Barbara and Celarent. So also of the "laws of nature," physical and chemical, so of natural history classifications - all were supposed to be exact and exclusive duplicates of prehuman archetypes buried in the structure of things, to which the spark of divinity hidden in our intellect enables us to penetrate. The anatomy of the world is logical, and its logic is that of a university professor, it was thought. (James 1978: 40)

James opposes this genetic transcendentalism with his naturalism, according to which the origin of the a priori structure of our mind must be explained as the result of natural selection:

the features of our mental structure [...] must be understood as congenital variations, "accidental" (in the Darwinian sense) in the first instance, but then transmitted as fixed features of the race. (James 1983: 1216) ${ }^{32}$

61 The question that must be asked is obvious: is Wittgenstein's functional transcendentalism compatible with James's genetic naturalism? And the answer, in principle, is in the affirmative. Except that there is a difference in their respective conceptions of philosophy which would explain why the young Wittgenstein (and also the later one, incidentally) would not have accepted James's naturalism.

In paragraph 4.1122 of the Tractatus, as a gloss on what comes immediately before it and in which, as we have seen, there is a warning against metaphilosophical psychologism, Wittgenstein says "Darwin's theory has no more to do with philosophy than any other hypothesis in natural science"; a remark that might perfectly well have been directed against James's genetic naturalism. But if Wittgenstein would oppose James's theses it would be not so much because of their naturalism as for their genetic character. No less would he have opposed a transcendentalism that shared it. In Tractatus 3.031 we read: "It used to be said that God could create anything except what would be contrary to the laws of logic. The truth is that we could not say what an 'illogical' world would look like."

The philosopher must abstain from formulating causal hypotheses, whether theological or natural, about why we think as we do. In part, this is what Wittgenstein wanted to indicate when, in his Notebooks, he wrote: "Logic must take care of itself." ${ }^{33}$ If we are asked why we think that the world is logical, the only thing that we can offer as a reason for it is that we could not think what an illogical world would be like. And the fact is that Wittgenstein always maintained an extraordinarily austere conception of philosophy, which he separated sharply from science, ${ }^{34}$ so philosophy had to remain 
within the limits of reasons and never enter the domain of causes. One of the perennial motives for Wittgenstein's reproaches of James, who had a much more tolerant - and in my view, let me say, much more appropriate - understanding of philosophy, in which there was room for causal considerations of a general nature.

So, although the functional transcendentalism of the first Wittgenstein's philosophy of logic is, in principle, not incompatible with the genetic naturalism of James's, for general metaphilosophical reasons the Austrian thinker would have rejected it. However, could the reciprocal statement be made with regard to James? Here, once again, some explanation is required.

It is true that James's genetic naturalism is, in principle, compatible with a Kantian transcendental understanding of logic and mathematics, but the fact is that James finds his inspiration not so much in the Königsberg philosopher as in the ideas that Locke puts forward in his Essay:

I have done nothing more in the previous pages than to make a little more explicit the teachings of Locke's fourth book [...] these eternal verities, these "agreements" which the mind discovers by barely considering its own "fixed meanings" [...]. None of these eternal verities has anything to say about facts, about what is or not in the world. (James 1983: 1256)

[N]ote the strange descent in Locke's hands of the dignity of a priori propositions. By the ancients they were considered, without farther question, to reveal the constitution of Reality. Archetypal things existed, it was assumed, in the relations in which we had to think them. The mind's necessities were a warrant for those of Being [...]. But the intuitive propositions of Locke leave us as regards outer reality none the better for their possession. We still have to "go to our senses" to find what reality is. The vindication of the intuitionist position is thus a barren victory. The eternal verities which the very structure of our mind lays hold of do not necessarily themselves lay hold on extra-mental being, nor have they, as Kant pretended later, a legislating character even for all possible experience. (James 1983: 1258)

That is to say, James would be in agreement with the intuitive, a priori character of mathematical and logical truths, but unlike the Kantian tradition - to which the first Wittgenstein would undoubtedly subscribe - he would not consider that those truths were a transcendental condition of all possible experience, or, therefore, that their objective validity was guaranteed. What this means is that for James, if we wish to know whether the world responds to our a priori intuitions, there is no alternative but to turn to experience, which always retains its potentiality for confutation. It is precisely this potentiality that explains the rise of mathematical and even logical alternatives. ${ }^{35}$

Whether this pluralism, which James assumes in his essay on "Humanism and Truth," is compatible with the explanation that he gave in his Principles of the a priori structure of our mind as the work of natural selection is a question on which we shall not express an opinion here. What is clear, in my view, is that the second Wittgenstein would be closer to this pluralism than the first one.

\section{The Psychological Self}

68 The comparison with James's points of view may also cast light on the first Wittgenstein's theses about the self; a very necessary light, given that the paragraphs 
of the Tractatus in which he deals with this question are undoubtedly among the most obscure ones in the book.

Starting at paragraph 5.54, we read:

5.54 In the general propositional form propositions occur in other propositions only as bases of truth-operations.

5.541 At first sight it looks as if it were also possible for one proposition to occur in another in a different way. Particularly with certain forms of proposition in psychology, such as "A believes that $p$ is the case" and "A has the thought $p$," etc. For if these are considered superficially, it looks as if the proposition $p$ stood in some kind of relation to an object A. (And in modern theory of knowledge (Russell, Moore, etc.) these propositions have actually been construed in this way.)

5.542 It is clear, however, that "A believes that p," "A has the thought $\mathrm{p}$," and "A says p" are of the form " $p$ ' says p": and this does not involve a correlation of a fact with an object, but rather the correlation of facts by means of the correlation of their objects.

5.5421 This shows too that there is no such thing as the soul - the subject, etc. - as it is conceived in the superficial psychology of the present day. Indeed a composite soul would no longer be a soul.

5.5422 The correct explanation of the form of the proposition, "A makes the judgement $p$," must show that it is impossible for a judgement to be a piece of nonsense. (Russell's theory does not satisfy this requirement.)

5.5423 To perceive a complex means to perceive that its constituents are related to one another in such and such a way. This no doubt also explains why there are two possible ways of seeing the figure

Figure 1

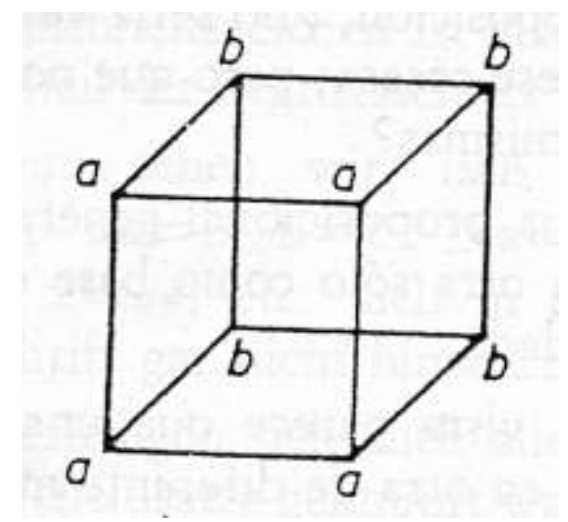

as a cube; and all similar phenomena. For we really see two different facts. (If I look in the first place at the corners marked a and only glance at the b's, then the a's appear to be in front, and vice versa.)

Fundamentally, these considerations of Wittgenstein's pose two hermeneutic problems: how would his analysis of psychological propositions overcome the principle of extensionality - "propositions occur in other propositions only as bases of truthoperations"? and what consequences does this analysis have for the conception of the subject? Here I will say nothing about the first of these two questions ${ }^{36}$ and I will concentrate exclusively on the second.

In this respect, it is evident that Wittgenstein wishes to oppose the conception of the subject that was initiated by the analysis of psychological propositions that appeared in the "modern theory of knowledge," with Russell and Moore counting as two of its most distinguished representatives, ${ }^{37}$ and that, in short, actually coincided, in his view, with 
the understanding of the soul characteristic of the "superficial psychology" of the time. But what was that conception?

At the time when he maintained the theory of judgement that Wittgenstein criticises in the Tractatus Russell also assumed a Cartesian conception of the subject and of selfknowledge..$^{38}$ The self is a simple object to which we have direct cognitive access in the psychological states that are self-representative. But Wittgenstein very soon realised that his analysis of psychological propositions as a relation with a complex, with a fact, implied that the subject of them could not be a simple object. And thus, in the Notes dictated to G. E. Moore in Norway in the early days of April 1914, we find:

The relation of "I believe $p$ " to " $p$ " can be compared to the relation of " $p$ ' says (besagt) p" to $\mathrm{p}$ : it is just as impossible that I should be a simple as that "p" should be. (Wittgenstein 1998: 119)

Thus the correct analysis of the logical form of psychological propositions that Wittgenstein proposes would amount to showing - a new amendment of Cartesianism that the subject of psychological attitudes cannot be a simple entity, a soul, but must be a complex entity, a set of mental facts. So it is quite plausible to suppose that, for Wittgenstein, psychology, as a natural science, would have the objective of determining the causal laws that govern the succession of our mental states. Precisely in the way in which James understood it.

And it is James himself, in The Principles of Psychology, who characterises the theory of the soul in a way that may help us to contextualise and better understand what it is that Wittgenstein was aiming at when he spoke of the "superficial psychology" of his time. James says:

The theory of the Soul is the theory of popular philosophy and of scholasticism, which is only popular philosophy made systematic. It declares that the principle of individuality within us must be substantial, for psychic phenomena are activities, and there can be no activity without a concrete agent. This substantial agent cannot be the brain but must be something immaterial; for its activity, thought, is immaterial [...]. Thought moreover is simple, whilst the activities of the brain are compounded of the elementary activities of each of its parts. Furthermore, thought is spontaneous or free, whilst all material activity is determined $a b$ extra [...]. For these objective reasons the principle of psychic life must be both immaterial and simple as well as substantial, must be what is called a Soul. The same consequence follows from subjective reasons. Our consciousness of personal identity assures us of our essential simplicity: the owner of the various constituents of the self [...], the hypothetical Arch-Ego [...] is a real entity of whose existence self-consciousness makes us directly aware [...]. The Soul then exists as a simple spiritual substance in which the various psychic faculties, operations, and affections inhere [...]. The consequences of the simplicity and substantiality of the Soul are its incorruptibility and natural immortality - nothing but God's direct fiat can annihilate it - and its responsibility at all times for whatever it may have ever done. (James 1983: 325-6; original emphasis)

James does not invent this position. In the first book of his Psychology from an Empirical Standpoint, to which we have already referred, Brentano assumes a conception of the soul practically identical to the one that James presents, while to psychology, for him the science of the future, as we already know, he attributes the additional advantage of the very important teachings about immortality with which it provides us (Brentano 1995: 19-20).

What we have, therefore, is a further coincidence between James and Wittgenstein: they both agree in opposing the Cartesian conception of the psychological subject, as 
they had previously coincided in opposing metaphilosophical psychologism and psychologism as philosophy of logic. Yet once again this coincidence should not hide their differences from us; for a start, methodological: Wittgenstein has come to his anti-Cartesian conclusion by means of the analysis of the logical forms of psychological propositions; whereas the path that has led James to an identical conclusion is his favourite psychological method: introspection. However, above all, although Wittgenstein and James agree in their theory of the psychological self, they do not agree, without further ado, in their theory of the self. For Wittgenstein, apart from the self, one can still speak of a metaphysical subject, a philosophical self, which is the limit of the world, not part of it:

Thus there really is a sense in which philosophy can talk about the self in a nonpsychological way. What brings the self into philosophy is the fact that "the world is my world." The philosophical self is not the human being, not the human body, or the human soul, with which psychology deals, but rather the metaphysical subject, the limit of the world - not a part of it. (Wittgenstein 2001: 5.641)

By now we should be able to guess the reason for this discrepancy. At this point, too, Wittgenstein is drawn to a transcendental focus with a Kantian affiliation, ${ }^{39}$ and he considers that it is necessary to postulate the existence of a metaphysical subject that accounts for the phenomenon of subjectivity, ${ }^{40}$ whereas James remains faithful to his naturalism derived from Locke ${ }^{41}$ and does not consider that there is a need to postulate any entity that, transcending the limits of experience, is at the same time a condition of it:

Transcendentalism is only Substantialism grown shame-faced, and the Ego only a 'cheap and nasty' edition of the soul. All our reasons for preferring the "Thought" to the "Soul" apply with redoubled force when the Soul is shrunk to this estate. The Soul truly explained nothing [...] but at least she had some semblance of nobility and outlook [...]. The Ego is simply nothing: as ineffectual and windy an abortion as Philosophy can show. ${ }^{42}$

For James, "Thought" is already intrinsically subjective, and it is sufficient to analyse the relations that exist between its different states - basically, of continuity and similarity - to give a reliable account of "The consciousness of Self."

\section{Conclusion}

The comparison of some of the theses of the first Wittgenstein with those that James maintained in his Principles shows the same complex pattern that other scholars have detected when the point of reference taken for the comparison is the thought of the second Wittgenstein. Their relation cannot be described solely as "critical and negative." As we have seen, James and Wittgenstein coincide in their opposition to metaphilosophical psychologism, to any attempt to reduce philosophy to a particular science, whether it be psychology or any other, in the same way that they coincide in their criticism of psychologism as philosophy of logic or of the Cartesian conception of the psychological subject. But these coincidences should not make us ignore their profound differences. Their opposition to psychologism and to Cartesianism is made from very different positions: that of an approach of a transcendental kind in the case of the first Wittgenstein, and from a naturalist perspective in the case of James. The fact that, as I understand it, from 1930 onwards Wittgenstein began to move towards 
more naturalist positions would only indicate that his closeness to James gradually increased with the years.

\section{BIBLIOGRAPHY}

BONCOMPAGNI A., (2012a), “'The Mother-Tongue of Thought': James and Wittgenstein on Common Sense," Cognitio: Revista de Filosofia, 13 (2).

BONCOMPAGNI A., (2012b), “Streams and River-Beds. James' Stream of Thought in Wittgenstein's Manuscripts 165 and 129," European Journal of Pragmatism and American Philosophy, IV (2).

BORDOGNA F., (2008), William James at the Boundaries: Philosophy, Science, and the Geography of Knowledge, Chicago, University of Chicago Press.

BRENTANO F., (1995), Psychology from an Empirical Standpoint, London, Routledge.

CALCATERRA R., (2015), "Constructing on Contingency: William James from Biology to Ethics and Politics," Cognitio, 16 (2).

CHAUVIRÉ C., (2010), “Les mirages de l'introspection: Wittgenstein critique de James," Revista Colombiana de Filosofía de la Ciencia, X (20-21).

DEL CASTILLO R., (1995), Conocimiento y acción. El giro pragmático de la filosofía, Madrid, Aula Abierta, UNED.

DILWORTH David A., (2011), “Peirce's Objective Idealism: A Reply to T. L. Short's 'What Was Peirce's Objective Idealism?', ' Cognitio: Revista de Filosofia, 12.

Goodman R., (2002), Wittgenstein and William James, Cambridge, Cambridge University Press.

JACKMAN H., (2006), “Wittgenstein \& James's 'Stream of Thought', " [yorku.ca/hjackman/papers/ WittJames.pdf].

JAMES W., (1892a/1920), “A Plea for Psychology as a 'Natural Science,," in Collected Essays and Reviews by William James, London, Longmans, Green and Co.

JAMES W., (1892b), Psychology, Briefer Course, New York, Henry Holt \& Co.

JAMES W., (1909), The Meaning of Truth: A Sequel to Pragmatism, London, Longmans, Green.

JAMES W., (1926), The Letters of William James, edited by Henry James, Boston, Little Brown.

JAMES W., (1978), Pragmatism and The Meaning of Truth: A Sequel to Pragmatism, Cambridge (Mass.), Harvard University Press.

JAMES W., (1983), The Principles of Psychology, Cambridge (Mass.), Harvard University Press.

KLEIN A., (2016), “Was James Psychologistic?,” Journal for the History of Analytical Philosophy, IV (5).

KUKLICK Bruce, (1977), The Rise of American Philosophy: Cambridge, Massachusetts, 1860-1930, New Haven, Yale University Press.

LEVIN J. D., (2002), Theories of the Self, London, Hemisphere Publishing Corporation. 
MONK R., (1991), Wittgenstein. The Duty of Genius, London, Vintage.

MOORE G. E., (1922), Philosophical Studies, London, Kegan Paul.

MYERS C., (1909), A Text-Book of Experimental Psychology, Cambridge, Cambridge University Press.

NUBIOLA J., (2000), “Ludwig Wittgenstein and William James," Streams of William James, 2 (3).

PADILlA J., (2010), “William James: Psicología y filosofía en diálogo,” Revista de Historia de la

Psicología, 31 (1-2).

QUINE W. V. O., (1969), Ontological Relativity and Other Essays, New York, Columbia University Press.

QUINTANILLA P., (2007), “Wittgenstein y la autonomía de la voluntad: la presencia del

pragmatismo," Revista de Filosofía 56.

RUSSELL B., (1910), Philosophical Essays, London, Longmans, Green.

RUSSELL B., (1984), The Collected Papers, vol. 7, London, Allen \& Unwin.

SANFÉLIX V., (2001), “La mirada distante. Wittgenstein y el pragmatismo," El retorno del

pragmatismo, edited by Arenas L., Muñoz J. \& Perona A. J., Madrid, Trotta.

SANFÉLIX V., (2007), “Un alma enferma. La experiencia religiosa

de Wittgenstein a la luz de Las variedades de la experiencia religiosa de William James," Dianoia, LII (59).

SANFÉLIX V., (2008), “'p’ dice p,” in Para leer a Wittgenstein, edited by Fernández Moreno L., Madrid, Biblioteca Nueva.

SANFÉLIX V., (2017), Wittgenstein. Una filosofía de la cultura, Madrid, Biblioteca Nueva.

SLUGA H., (1996), "Wittgenstein on the Self," in The Cambridge Companion to Wittgenstein, edited by Sluga H. \& Stern D. G., Cambridge, Cambridge University Press.

WITTGENSTEIN L., (1981), Personal Recollections, edited by Rhees R., Oxford, Blackwell.

WITTGENSTEIN L., (1998), Notebooks 1914-1916, edited by Wright G. H. von \& Anscombe G. E. M., Oxford, Basil Blackwell.

WITTGENSTEIN L., (2000), Wittgenstein's Nachlass. The Bergen Electronic Edition (BEE), Oxford, Oxford University Press.

WitTGENSTEIN L., (2001), Tractatus Logico-Philosophicus, London, Routledge.

WITTGENSTEIN L., (2009), Philosophical Investigations, Oxford, Wiley-Blackwell.

WITTGENSTEIN L., (2012), Wittgenstein in Cambridge. Letters and Documents 1911-1951, edited by

McGuiness B., Oxford, Wiley-Blackwell.

\section{NOTES}

1. In the Nachlass, James's name is mentioned 90 times. In the Philosophical Investigations James is referred to as many times as Frege, and only less than St Augustine.

2. To use Boncompagni's expression (2012b: 37).

3. See Wittgenstein (2012: 30, and 1981: 121). I devoted a paper, Sanfélix 2007, included as Ch. 1 in Sanfélix 2017, to specifying the - tremendous - influence that this book had on Wittgenstein.

4. Monk (1991: 477). For a brief exposition of Wittgenstein's relation with James's work, see Nubiola 2000. 
5. In the important Chapter VII of his Principles, "The Methods and Snares of Psychology," James recommends the use of three different methods for the construction of psychology as a "natural science": "Introspective Observation," "The Experimental Method" and "The Comparative Method." Of these three methods, it will be evident to the unprejudiced reader that the one most used by James in the writing of his book was, by far, the first, the introspective method, followed by the comparative method. On Wittgenstein's criticism of James's conception of introspection, Chauvire 2010 is worthwhile. Nevertheless, there have also been those who disagree that James was "a classical exponent of the tradition in the philosophy of mind that [Wittgenstein] was opposing." See Jackman 2006.

6. See also the "Preface" (James 1983: 6).

7. In any case, for this question, here and now I recommend a reading of Bordogna 2008 and Padilla 2010. Apart from the Principles.

8. In the enumeration of "the sources of error in Psychology" that James makes in Chapter VII of his Principles he indicates that "The first of them arises from the Misleading Influence of Speech" (James 1983: 193; original emphasis).

9. "The reader will in vain seek for any closed system in the book. It is mainly a mess of descriptive details, running out into queries which only a metaphysics alive to the weight of her task can hope successfully to deal with" (James 1983: 6-7).

10. Proceeding from this consideration, one has only to apply a minimum of interpretative charity to understand that James did not want to identify or reduce the self to any set of "peculiar motions in the head and between the head and throat." It is easy to understand the aptness of the title of the chapter that Levin (2002: Ch. 7) devotes to the study of James's understanding of the self: "The Multiplicity of the Self."

11. Only exceeded in length by Chapter XX, devoted to "The Perception of Space."

12. To the works by Goodman, Boncompagni and Jackman to which we have already referred we must add an ever longer list of authors who note their coincidences in various matters. For example: once again Boncompagni 2012b; Quintanilla 2007; Sanfélix 2001, included in Sanfélix 2017 as Ch. 5; del Castillo 1995; and so on.

13. Wittgenstein (2012: 30; original emphasis).

14. Charles Myers was the lecturer on psychology in Cambridge, author of A Text-Book of Experimental Psychology (1909), who directed the experiments on psychology of music that Wittgenstein conducted in 1912.

15. That year Russell published "Transatlantic Truth," an article that was followed in 1909 by "Pragmatism." James responded to the objections contained in the first of these two works of Russell's in the same year, 1908, in his article "Two English Critics," included the following year as the final chapter of his book The Meaning of Truth: A Sequel to Pragmatism (James 1909).

16. Included in Volume 7 of The Collected Papers of Bertrand Russell (Russell 1984).

17. Written in September 1913, just after returning from his first journey to Norway, during which he had been accompanied by his friend David Pinsent. These notes, of which two different versions are preserved, are included in the edition of his Notebooks 1914-16 (Wittgenstein 1998).

18. "Non-cognitive mental facts - feeling, emotion, volition" (Russell 1984: 22).

19. "It always appears to deal with objects independent of itself" is the fourth characteristic that James attributes to thought in Chapter IX of his Principles, devoted to determining the nature of “The Stream of Thought" (James 1983: 220).

20. See Russell (1984: 35).

21. Russell (1984: 46).

22. "Let me point out merely in passing that psychology contains the roots of aesthetics, which, in a more advanced stage of development, will undoubtedly sharpen the eye of the artist and assure his progress. Likewise, suffice it to say that the important art of logic, a single improvement in which brings about a thousand advances in science, also has psychology as its 
source. In addition, psychology has the task of becoming the scientific basis for a theory of education, both of the individual and of society. Along with aesthetics and logic, ethics and politics also stem from the field of psychology. And so psychology appears to be the fundamental condition of human progress in precisely those things which, above all, constitute human dignity" (Brentano 1995: 15-6).

23. "Perhaps it alone will be in a position to provide us the means to counteract the decadence which sadly interrupts the otherwise steadily ascending cultural development from time to time" (Brentano 1995: 16).

24. Counter to the more usual readings that generally attribute some form of psychologism to James. See Kuklick 1977; Dilworth 2011; and even Bordogna 2008.

25. "In our dealings with natural phenomena the great point is to be able to foretell," James wrote later in his essay "Humanism and Truth" James (1978: 51).

26. The same essay on "Humanism and Truth" abounds in declarations such as: "Experience is a process that continually gives us new material to digest" or "The fundamental fact about our experience is that it is a process of change" (James 1978: 42, and 54).

27. See James (1920: 318).

28. If, however, by metaphysics we understand, as James did, only "an unusually obstinate attempt to think clearly and consistently," then we would have to say that the anti-psychologism of the second Wittgenstein would be very close to that of James himself.

29. See James (1978: 152).

30. I enlarged on the aspects of the metaphysics of the Tractatus that are compatible with pragmatism, especially James's, in Sanfélix 2001.

31. On this matter there is an enlightening essay by Klein 2016.

32. On James's darwinisn, see Calcaterra 2015.

33. Wittgenstein (1998: 22.8.14). See also Wittgenstein (2001: 5.473).

34. "It was correct that our considerations must not be scientific ones" (Wittgenstein 2009: $\S 109)$.

35. See James (1978: 40).

36. I devoted Sanfélix 2008 to this theme.

37. Since Wittgenstein mentions Russell's theory of judgement, it is very likely that in these paragraphs he was thinking of the essays that Russell devoted to this question, such as "On the Nature of Truth and Falsehood," contained in his volume of Philosophical Essays, in which there are also some of his essays on James and pragmatism, Russell 1910. As for Moore, it is most probable that Wittgenstein had in mind the talk that he gave in the Aristotelian Society in 1910, "The Nature and Reality of Objects of Perception," (Moore 1922), of which he asked Russell to send two copies to him in Norway in October 1913. See Wittgenstein (2012: 49).

38. Although in his ill-fated Theory of Knowledge of 1913 he had already begun to express reservations and he soon ended up by retracting from it.

39. But at this point basically passed through the sieve of Schopenhauer.

40. See Sluga (1996: 329). Incidentally, Sluga is one of the few authors who considers it plausible that at some point in his treatment of the question of the self the first Wittgenstein may have been inspired by James's Principles. See Sluga (1996: 352n11). Obviously, I agree with him.

41. Although I would say that at this point it was passed through the sieve of Hume, and this despite James's criticisms of the associationist tradition to which the Scottish thinker subscribed. 42. James (1983: 345; original emphasis). The curious thing is that Wittgenstein could be fairly in agreement with this diagnosis of James's: "Here it can be seen that solipsism, when its implications are followed out strictly, coincides with pure realism. The self of solipsism shrinks to a point without extension, and there remains the reality co-ordinated with it" (Wittgenstein 2001: 5.64).

European Journal of Pragmatism and American Philosophy, IX-1 | 2017 


\section{ABSTRACTS}

Although it is not documentarily proven, it is not unlikely that the young Wittgenstein read at least part of William James's psychological work. In this paper we have compared their respective points of view about psychologism and the conception of the self. The result is a complex pattern of similarities and differences. If James and the early Wittgenstein coincide in their opposition to psychologism and the Cartesian conception of the subject, they do so from very different philosophical positions: that of a naturalist focus in the case of the American thinker; that of a transcendental focus in the Austrian thinker.

\section{AUTHOR}

\section{VINCENTE SANFELIX VIDARTE}

Universidad de Valencia

vicente.sanfelix[at]uv.es 